\title{
Effect of Different Substrates with Organic and Inorganic Fertilization under Closed System Condition on Lettuce Production
}

\author{
Melad H. Zaky and Fahima H. Ayoub \\ Veg. Res. Dept. Hort. Res. Inst., Agric. Res. Cent., Egypt \\ Corresponding Author: mervath77@Yahoo.Com
}

\begin{abstract}
Growing medium and fertilization are the most effective methods for controlling and improving the vegetative growth characteristics, head quality, yield and nutritional value of lettuce. Therefore the aim of this study was to determine the effect of different growing media when using organic or inorganic fertilization that associated with closed system on lettuce production in soilless culture system. Planting was conducted on Ashape system under unheated plastic greenhouse conditions. Experimental treatments included two nutrient solutions (mineral nutrient and compost tea) and seven substrates i.e. Peat moss, Perlite, Coir, Rice straw, Compost, Peat moss + Perlite (1:1 v:v) and Coir + Perlite (1:1 v:v). Results revealed that mineral fertilizer had better mean values for all measured vegetative growth parameters, total yield, NPK and chlorophyll content compared with organic fertilizer. The best vegetative growth characters in terms of leaf length, width, and area, number of leaves, head firmness, surround and weight, total yield, NPK and chlorophyll contents were occurred $100 \%$ in coir or peat. The most favorable beneficial interaction treatments regarding the previous growth characters were produced in plants which planted in coir or peat moss with mineral fertilizers. The results indicated that lettuce plants on the peat moss substrate with organic solution grew healthier, but the heads were small and the yield was decreased compared with the inorganic solution. The study revealed that, differences in nutrient fertilizers and growing substrates were significant and their influences have affected the growth and yield of lettuce when cultivated under controlled environment. This study showed that mineral fertilizer had better mean values for all measured growth parameters. While, peat moss and coir substrates proved to be the best growing for lettuce. This growing media enable the roots to develop better. Thus paving the way for plants to absorb more nutrients than the plants grown in other different substrates.
\end{abstract}

Key words: Lettuce- mineral fertilizer- organic fertilizer- growing substrates

\section{Introduction}

Lettuce (Lactuca sativa L.) is an annual herbaceous vegetable of the Asteraceae family, and represents an important source of mineral salts, mainly calcium and vitamins (Filgueira, 2003). Being one of the most cultivated and consumed vegetable crops in Egypt. This is due to several factors, such as its adaptability to varied climatic conditions.

It is well known that soilless culture offers an alternative method to soil culture when serious soil and water problems (i.e., soil born pests, soil and water salinity, chemical residues in soil, water salinity, lack of fertile soil, water shortage, etc.), create difficulties in traditional production in the soil. The main advantages of soilless culture are the most accurate control over the supply of water, nutrients, $\mathrm{pH}$, roots temperature, etc., which increase productivity due to easier and more accurate control of production factors such as reduction of labor requirement, as well no need for soil sterilization, in addition getting more crops per year, etc.

Hydroponics is the art of growing plants in a soilless medium. Worldwide, a high percentage of the hydroponics industry are used an inorganic growing media such as perlite, vermiculite, and others (San Bautista et al., 2005; Böhme et al.,
2008), while only about $12 \%$ uses organic growing media (Donnan, 1998) such as peat moss, coir and others. Growth media provide aeration and water, enhance root growth and physically support the plant (Olle et al., 2012).

The growing substrates are differing in their physical, chemical and biological properties (Herrera et al., 2008), therefore, substrate selection is one of the most important factors affecting plant growth and influencing vegetable quality. The physical properties, including water holding capacity, porosity, air space and bulk density, can vary greatly. These properties dictate the plant's ability to uptake water and nutrients, and even a small change in one of these parameters can result in poor plant performance (Fonteno, 1996). The desirable physical properties of a substrate are essential to optimal plant performance and each greenhouse crop may require different physical properties from the substrate along with best management practices to ensure this performance is met (Raviv, 2002). Therefore, it is possible to improve the quality of fruit by suitable substrate is chosen (Gruda, 2009). Also, the physical and chemical characteristics of the media which together with the growing techniques (e.g., fertigation) employed, will determine the yield and quality of the vegetables that are produced (Grunert et al., 2008). Bohlin and Holmberg (2004) reported 
that the physical properties of peat moss are (low bulk density, high porosity, high water holding capacity). The physical properties of coir have proven to be similar to those of peat moss for water adsorption and drainage (Meerow, 1994 and 2007). Research has also indicated a potential to increase water holding capacity in a growing substrate when coir is incorporated (HernándezApaolaza, et al., 2005). Perlite showed high total pore space, higher than $93 \%$, but low water holding capacity and $\mathrm{pH}$ was in the range of 5.9-6.8 (Kang $\boldsymbol{e t}$ al., 2004).

Tzortzakis and Economakis (2008) found that plants grew faster in organic media compared to inorganic media. In this respect peat moss is a light material with a relatively low $\mathrm{pH}$, an important factor in nutrient uptake (Reed, 1996), but most importantly it has a high water holding capacity (Bergeron, 1994) which plays an important role in plant growth. Coconut fiber is an absolutely (100\%) organic substrate. it is inert substrate as its size does not change but restrains huge amount of water. Coconut fiber other properties such as it is typical to absorb warmth, do not get salty and it has no pathogens and weeds seeds (Carrijo et al., 2004).

In a comparison between peat and straw substrates, the microorganisms need mineral nitrogen (N) for rice straw decomposition, which they gain from the available $\mathrm{N}$ content in the substrate, therefore $\mathrm{N}$ would not be readily available for the plants (Gruda, 2009) and a shortage of $\mathrm{N}$ will be appearing in this crop (Abd El- Sattar et al., 2008).

Furthermore, there is a growing body of studies indicating the benefit of mixing organic and inorganic components for vegetable growing media with improved performance in greenhouse production (Gao et al., 2010). Addition of inorganic substances to organic substances produces higher yield probably owing to increasing water-holding capacity and aeration by organic substances, which demonstrates that inorganic substances could partially replace organic substances (Gao et al., 2010).In this respect perlite is used in addition to peat moss in growing substrates to increase air space and improve drainage (Perlite Canada, 2010).Also, peat moss and their mixes with perlite are the most widely used substrates in growing and productivity of several vegetables crop (Gao et al., 2010).

Compost tea is one of the alternative techniques extracted from composted materials by steeping or brewing the compost in water using various preparation methods (Scheuerell and Mahaffee, 2002; Litterick et al., 2004) to extract anaerobic microbes and nutrients which are used and applied to promote plant health and vitality (Scheuerell and Mahaffee, 2002; Naidu et al., 2010). However, Nutrient value of organic composts varies widely depending upon the nature of the composted feedstock (Abu-Zahra and Tahboub, 2008).
The commercial organic hydroponic food production is still in its infancy. The growing lettuce in soilless culture for production are known for their efficiency and sustainability, but due to many of the chemicals utilized (i.e. fertilizers, $\mathrm{pH}$ adjusters) are traditionally "inorganic" in nature. With rising demand for "organic" produce there is much interest in converting these traditional systems to ones that meet the criteria to be classified as "Certified Organic".

The aim of the present study is to investigation the suitability of using different growing substrates with organic and inorganic nutrient solution on lettuce production in closed system under greenhouse.

\section{Materials and Methods}

This Experiment was carried out in the greenhouse of the Vegetable Crops Department, Horticulture Research Institute, Agriculture Research Center, Giza, throughout the two growing winter seasons of 2016/2017 and 2017/2018 to study the effect of some substrates or mixture of substrates with organic and inorganic fertilization that associated with closed fertigation system on lettuce production under plastic greenhouse conditions. Lettuce seeds $\mathrm{Cv}$. Limor HYB were sown on November 29, 30 for the first and second season respectively. Lettuce seeds were sown in transplanting trays (209 cells). Three weeks old healthy and vigorous seedlings were transplanting to metal A- shape system of soilless culture under greenhouse conditions. The experiment was designed in a split plot arrangement with three replicates, each replicate included fourteen treatments which were the combination of two fertilizers as main plots and seven growing substrates were arranged within the sub- plots. Each treatment consists of ten plants per replicate. Lettuce seedlings were transplanted into PVC pipes filled with seven growing substrates. The spaces between plants were $20 \mathrm{~cm}$ (18 plants per $\left.\mathrm{m}^{2}\right)$.

\section{Closed system:}

Closed system hydroponics is a method which the nutrient solution is re-circulated throughout the system to reduce the fertilizers by $57-77 \%$ and water by $60-80 \%$ (Nederhoff and Stanghellini 2010). A metal A- shape system of soilless culture was used to present the substrate systems. The metal A- shape frame $(0.9 \mathrm{~m}$ width and $1.3 \mathrm{~m}$ height $)$ included three levels of PVC pipes (4inch) on the two sides. The PVC pipes were holed every $20 \mathrm{~cm}$. the A- shape performed plant density of 18 plants per square meter. The PVC pipes filled with the different studied substrate (alone or mixing) for illustrating the substrate culture system. The cultivated lettuce plants were irrigated by using a small flexible pipe at the top of the PVC pipes usually introduces the nutrient solution. This system had a sloping $1 \%$. Different 
nutrient solutions were pumped via submersible pump (110watt). The drainage was collected back to the tanks of the different systems in the close type of soilless culture. The fertigation rate was programmed to be 8 times /day for 5 mints per one time.

\section{Fertilizers:}

Two fertilizers solutions (i.e. mineral and organic fertilizer solutions) were used in this study illustrated with 2 EC (Electro Conductivity) and $6.5 \mathrm{pH}$ was circulated daily. The mineral solution was prepared as shown in Table (1), while the organic solution (Compost tea) was prepared by soaking $2 \mathrm{Kg}$ compost in water tank (8L) for two days, then, filtered using gauze the compost suspension. The net filtered was used as stock nutrient solution. The chemical composition of compost in two growing seasons are shown in Table (2).

\section{Growing substrates:}

Seven growing substrates were used in this study i.e. Peat moss, Coir, Rice straw, Compost, Perlite, mixture of Peat moss + Perlite (1:1 v:v) and Coir + Perlite (1:1 v:v).
The physical and chemical properties of the substrates:

The physical (Bulk density, Total porosity, Air filled porosity and water holding capacity) and chemical ( $\mathrm{pH}$ and electrical conductivity) properties of the substrates and substrates mixtures were determined at the beginning of the experiment according to the methodology suggested by Fonteno (1996) using the following equation:

Bulk density $(\mathrm{g} \mathrm{cm}-3)=($ dry weight $\mathrm{x}$ 100) / (substrate volume)

Total porosity $(\% \mathrm{v} / \mathrm{v})=[($ wet weight - dry weight $)+$ drained volume $\mathrm{x} 100] /$ (substrate volume)

Air-filled porosity $(\% \mathrm{v} / \mathrm{v})=[($ drained volume $\mathrm{x} 100)$ / (substrate volume)

Water-holding capacity $(\% \mathrm{v} / \mathrm{v})=[($ wet weight - dry weight) $\mathrm{x} \mathrm{100]/} \mathrm{(substrate} \mathrm{volume)}$

The $\mathrm{pH}$ and $\mathrm{EC}$ of the nutrient solution were measured daily using a $\mathrm{pH}$ and EC meter (HANNA Instrument) basis from transplanting to harvesting and maintained within a range of 5.5 to 6.5 and 1.5 to $2.0 \mathrm{mS} \mathrm{cm}-1$ in all treatments, respectively.

The physical and chemical properties of the substrates were arranged in a randomized complete block design with three replications.

Table 1. Weight $(\mathrm{g})$ of substances to be dissolved in 40liters of water to make mineral stock solution.

\begin{tabular}{llll}
\hline Elements & Solution A & Solution B & Solution C \\
\hline Calcium nitrate & $11 \mathrm{~kg}$ & - & - \\
EDDHA (Fe) 6\% & $600 \mathrm{~g}$ & - & - \\
Compound fertilizer 19:19:19 & - & $6.300 \mathrm{~kg}$ & - \\
Magnesium sulfate & - & $1.2 \mathrm{~kg}$ & - \\
Small elements & - & $400 \mathrm{~g}$ & - \\
phosphoric acid & - & & 2 liters \\
\hline
\end{tabular}

Table 2. Chemical composition of compost.

\begin{tabular}{|c|c|c|c|c|c|c|c|c|c|c|}
\hline & \multicolumn{4}{|c|}{ Nutrient elements (\%) } & & \multicolumn{3}{|c|}{ Heavy metals (ppm) } & \multirow[t]{2}{*}{ O.M\% } & \multirow{2}{*}{$\begin{array}{l}\mathrm{C} / \mathrm{N} \\
\text { ratio }\end{array}$} \\
\hline & $\mathrm{N}$ & $\mathrm{P}$ & $\mathrm{K}$ & $\mathrm{Ca}$ & $\mathrm{Mg}$ & $\mathrm{Pb}$ & $\mathrm{Cd}$ & $\mathrm{Co}$ & & \\
\hline Compost & 1.12 & 0.26 & 0.29 & 0.13 & 0.24 & 85.96 & 1.35 & 21.96 & 34.3 & 15.31 \\
\hline
\end{tabular}

Chemically available, $\mathrm{mg} / \mathrm{kg}^{-1}$ were $\mathrm{N} 986, \mathrm{P} 474$, and K 465

Data recorded:

\section{Vegetative growth characteristics:-}

After 60 days from transplanting, the plants were harvested and measured for fresh and dry weight, leaf length and width, leaf area (method as described by Yoshida et $\boldsymbol{a l . ,} 1997$ and leaf number.

\section{Lettuce head quality and yield}

Head surround, $(\mathrm{cm})$, head firmness $\left(\mathrm{kg} / \mathrm{cm}^{2}\right)$ was recorded by using penetrometer mod. FT327 and total yield $\left(\mathrm{kg} / \mathrm{m}^{2}\right)$ were recorded.

\section{Leaves chemical composition:}

Data were recorded on the following:

1) Leaves chlorophyll content that determined by Minlolta chlorophyll meter SPAD $-50 \%$.

2) Nitrogen, phosphorus and potassium contents: Nitrogen content was determined in the digested solution by the" Modified micro- Kheldahl" method as described by Plummer (1971).
Phosphorus was determined calorimetrically according to the method of Jakson (1973). While potassium was measured using "flamphotometer" as described by Brown and Lilliand (1964)

\section{Statistical analysis:}

The obtained data were subjected to the analysis of variance procedure and means and compared using the L.S.D. method at 5\% level of significance according to Snedecor and Cochran (1980).

\section{Results and Discussion}

\section{The physical and chemical properties of the substrates:}

Data illustrated in Table (3) showed some physiochemical properties of substrates.

1.1. The physical properties of the substrates 
1.1.1. Bulk density: Bulk density is considered one of the most important substrates characteristics, which describe the status of substrates structure. The illustrated data in Table (3) cleared that high bulk density was found in small substrate particles such as compost (0.55) while coir $(0.08 \mathrm{~g} / \mathrm{cm}-3)$, perlite $(0.13)$ and rice straw $(0.10)$ has the lowest values. These results are agreed with those reported by Noguera et al. (2003) and Fahima et al., (2013) who found that the bulk density of compost is from 0.30 to $0.75 \mathrm{~g} / \mathrm{cm}-3$.

1.1. 2. Total porosity: Total porosity is one of the most common criteria for substrate structure status. The results in Table (3) showed that the high total porosity was found in coir (95.0), peat moss (86.6) and perlite (84.5) while, the lowest total porosity was found in compost (73.4) substrates. This result indicated that the lowest in bulk density of substrate led to increase its total porosity. These results are agreed with those reported by Bunt (1984); Pardossi et al. (2011) and Fahima et al. (2013) who found that total porosity was inversely related to bulk density. Results also show that, added perlite in substrate mixtures lead to increase its total porosity which improved also their water drainage.

1.1.3. Air filled porosity: Peat moss and coir substrates had no differences in their proportion of air filled porosity while there were differences in between them concerning the water holding capacity. Therefore, (peat moss or coir + perlite) substrates mixtures have the highest air filled porosity values which indicate that the root media aeration in these substrates is better than others. These results may be due to the increase of substrate total porosity which will lead increase of proportion and amount of air filled porosity.
1.1.4. Water holding capacity: This property refers to the space filled by water which will help us to know how much water needs for the substrate to give a crop. Different media components contribute to water holding capacity at various levels. Results in Table (3) showed that substrate has finer particles and spores, such as peat moss, coconut coir, hold more water. In contrast, those with larger, coarser particles, such as perlite, and rice straw hold little water. Therefore added perlite in substrate mixtures led to decrease its water holding capacity. These results may be due to the increase of substrate total porosity which will lead increase of proportion and amount of water in the pore space. This result agrees with Herrera et al., (2008) who reported that the growing substrates are differ in their physical and chemical properties. Similar result was reported on substrates physical properties as Meerow (2007) and Olle et al., (2012) on peat moss and HernándezApaolaza, et al., (2005)on coir; Kang et al., (2004) on perlite.

Also, Bergeron (1994) who reported that peat moss has a high water holding capacity. Moreover, Gao et al., (2010) found that addition of inorganic substances such perlite to organic substances lead to increase of water-holding capacity and aeration by organic substances. Also, Perlite Canada, (2010) who reported that addition of perlite to peat moss in growing substrates lead to increase air space and improve drainage.

\subsection{The chemical of the substrates}

High $\mathrm{pH}$ and electrical conductivity (EC) were found in compost substrate. The incorporation of coir and peat moss in the substrates gave the lowest value of $\mathrm{pH}$ while peat moss and Peat moss + Perlite gave the lowest value of EC respectively.

Table 3. Physical and chemical properties of the substrates

\begin{tabular}{|c|c|c|c|c|c|c|}
\hline & $\begin{array}{l}\text { Bulk density } \\
(\mathrm{g} \mathrm{cm}-3)\end{array}$ & $\begin{array}{l}\text { Total } \\
\text { porosity } \\
(\% \mathrm{v} / \mathrm{v})\end{array}$ & $\begin{array}{l}\text { Air filled porosity } \\
\qquad(\% \mathrm{v} / \mathrm{v})\end{array}$ & $\begin{array}{c}\text { Water holding } \\
\text { capacity } \\
(\% \mathrm{v} / \mathrm{v})\end{array}$ & $\mathrm{pH}$ & $\begin{array}{l}\mathrm{Ec} \\
(\mathrm{ds} / \mathrm{m})\end{array}$ \\
\hline Peat moss & 0.17 & 86.6 & 10.4 & 76.2 & 3.62 & 0.26 \\
\hline Coir & 0.08 & 95.0 & 15.7 & 79.3 & 5.78 & 0.83 \\
\hline Compost & 0.55 & 73.4 & 8.0 & 65.4 & 7.32 & 2.33 \\
\hline Perlite & 0.13 & 84.5 & 33.0 & 51.5 & 6.96 & 0.29 \\
\hline Rice straw & 0.10 & 83.0 & 22.0 & 61.0 & 6.80 & 1.45 \\
\hline Peat moss + perlite & 0.26 & 93.0 & 39.0 & 54.0 & 6.70 & 0.27 \\
\hline Coir + perlite & 0.16 & 91.0 & 38.0 & 53.0 & 7.12 & 0.59 \\
\hline LSD at $5 \%$ & 0.15 & 4.2 & 4.3 & 1.02 & 0.01 & 0.03 \\
\hline
\end{tabular}

\section{Vegetative growth characteristics:-}

Results in Table (4) showed the effect of growing medium and fertilization on the vegetative growth characteristics i.e. Leaf length, Leaf width, Leaf area and No. of leaves/plant of lettuce crop grown in soilless culture system.

Concerning the effect of organic (Compost tea) and inorganic fertilization on lettuce vegetative growth characteristics, data in Table (4) showed that mineral fertilizer significantly encouraged the previous vegetative growth characteristics as compared to organic fertilizer through the two studied seasons. However, lettuce plants grown in different substrates and fertigated with compost tea solution had completed their life cycles and appeared visually healthier, although those plants were 
smaller, than the plants grown in the same substrates and fertigated with inorganic nutrient solution. This result agrees with Scheuerell and Mahaffee, (2002); Naidu et al., (2010) who reported that the use of compost tea will promote plant health and vitality. Results showed that organic nutrient solution decrease the vegetative growth characters of lettuce by $7.7 \%, 11.8 \%, 20.8 \%$ and $8.0 \%$ for leaf length, leaf width, leaf area and number of leaves per plant, respectively during the first season and $6.4 \%, 10.0 \%$, $20.4 \%$ and $9.0 \%$ for previous characters respectively during the second season in comparison to inorganic nutrient solution. Concerning the effect of growing medium on lettuce vegetative growth characters, data showed, that the maximum growth characters were observed in plant grow on peat moss and coir substrates with no significant in between them followed by substrates mixture i.e. Peat moss + Perlite and Coir + Perlite compared to the other organic and inorganic media during the two studied seasons. These results may be due to the physical and chemical characters of these substrates as shown in previous results which have benefit effect on improving the vegetables growth characteristic as reported by Grunert et al. (2008). These results indicate that the physical and chemical properties of a substrate are essential to optimal lettuce crop performance and this crop require different substrate physical properties from the substrate along with best management practices to ensure this performance as reported by Raviv (2002). Moreover, the increase in bulk density is associated with decrease in total pore space and thus affects growth mainly through the effects of reduced free pore space. Also, the increase in total pore space in these previous substrates may be lead to decrease the water retention, increase oxygen transport and increase root penetration as reported by (Michael and Lieth, 2008). This result agree with Tzortzakis and Economakis (2008) who found that plants grew faster in organic media compared to inorganic media. Also, Bergeron, (1994) who reported that peat moss has a high water holding capacity which plays an important role in plant growth. This result also, indicated that there are benefits of mixing organic and inorganic components (i.e., peat moss + perlite and coir + perlite substrate) for vegetative growth characteristics of lettuce. Similar results were reported by (Gao et al., 2010).

Table 4. Effect of different substrates with organic and inorganic fertilization that associated with closed system on vegetative growth characters of lettuce

\begin{tabular}{|c|c|c|c|c|c|c|c|c|c|}
\hline \multirow{2}{*}{\multicolumn{2}{|c|}{ Treatments }} & \multicolumn{2}{|c|}{$\begin{array}{l}\text { Leaf length } \\
(\mathrm{cm})\end{array}$} & \multicolumn{2}{|c|}{$\begin{array}{l}\text { Leaf width } \\
\text { (cm) }\end{array}$} & \multicolumn{2}{|c|}{$\begin{array}{l}\text { Leaf area } \\
\left(\mathrm{cm}^{2}\right)\end{array}$} & \multicolumn{2}{|c|}{$\begin{array}{l}\text { No. of leaves } \\
\text { /plant }\end{array}$} \\
\hline & & 2016 & 2017 & 2016 & 2017 & 2016 & 2017 & 2016 & 2017 \\
\hline \multirow{2}{*}{\multicolumn{2}{|c|}{$\begin{array}{l}\text { Mineral fertilizer } \\
\text { Organic fertilizer }\end{array}$}} & 21.62 & 23.19 & 20.24 & 23.70 & 420.31 & 443.84 & 35.29 & 38.76 \\
\hline & & 19.95 & 21.71 & 17.86 & 21.33 & 332.97 & 353.48 & 32.48 & 35.29 \\
\hline \multicolumn{2}{|c|}{ L.S.D. at $5 \%$} & 0.54 & 0.71 & 0.89 & 0.41 & 10.30 & 43.32 & 1.64 & 0.54 \\
\hline \multicolumn{2}{|c|}{ Coir } & 23.83 & 24.33 & 21.17 & 26.33 & 478.52 & 527.28 & 37.33 & 43.00 \\
\hline \multicolumn{2}{|c|}{ Perlite } & 20.17 & 21.33 & 18.83 & 21.33 & 314.74 & 331.01 & 33.50 & 35.50 \\
\hline \multicolumn{2}{|c|}{ Coir + perlite } & 21.17 & 22.83 & 20.33 & 22.00 & 371.45 & 391.21 & 34.67 & 38.67 \\
\hline \multicolumn{2}{|c|}{ Peat moss } & 24.17 & 24.67 & 21.50 & 26.33 & 500.77 & 531.98 & 37.50 & 43.00 \\
\hline \multicolumn{2}{|c|}{ Peat moss + perlite } & 21.33 & 23.00 & 20.17 & 22.17 & 370.61 & 391.58 & 35.17 & 40.17 \\
\hline \multicolumn{2}{|c|}{ Rice straw } & 15.50 & 20.00 & 13.50 & 19.33 & 300.20 & 306.85 & 27.83 & 28.67 \\
\hline \multicolumn{2}{|c|}{ Compost } & 19.33 & 21.00 & 17.83 & 20.33 & 300.40 & 310.73 & 31.17 & 30.17 \\
\hline \multicolumn{2}{|c|}{ L.S.D. at $5 \%$} & 0.82 & 1.24 & 0.80 & 0.99 & 14.67 & 23.26 & 0.86 & 1.37 \\
\hline \multirow{7}{*}{ Mineral } & Coir & 24.33 & 25.00 & 22.00 & 27.67 & 508.67 & 566.09 & 38.67 & 44.33 \\
\hline & Perlite & 21.00 & 21.33 & 20.00 & 22.33 & 358.12 & 369.40 & 34.33 & 38.00 \\
\hline & $\begin{array}{l}\text { Coir + } \\
\text { perlite }\end{array}$ & 21.67 & 23.67 & 21.33 & 22.67 & 367.86 & 395.91 & 35.00 & 39.00 \\
\hline & Peat moss & 25.67 & 26.33 & 23.33 & 28.00 & 615.73 & 633.02 & 39.33 & 45.33 \\
\hline & $\begin{array}{l}\text { Peat moss + } \\
\text { perlite }\end{array}$ & 22.67 & 24.00 & 21.67 & 23.33 & 418.95 & 440.72 & 36.67 & 43.67 \\
\hline & Rice straw & 16.00 & 20.67 & 14.00 & 20.00 & 337.80 & 349.60 & 31.33 & 29.67 \\
\hline & Compost & 20.00 & 21.33 & 19.33 & 21.67 & 335.06 & 352.16 & 31.67 & 31.33 \\
\hline \multirow{7}{*}{ Organic } & Coir & 23.33 & 23.67 & 20.33 & 25.00 & 448.37 & 488.47 & 36.00 & 41.67 \\
\hline & Perlite & 19.33 & 21.33 & 17.67 & 20.33 & 271.04 & 292.61 & 32.67 & 33.00 \\
\hline & $\begin{array}{l}\text { Coir }+ \\
\text { perlite }\end{array}$ & 20.67 & 22.00 & 19.33 & 21.33 & 375.04 & 386.50 & 34.33 & 38.33 \\
\hline & Peat moss & 22.67 & 23.00 & 19.67 & 24.67 & 385.8 & 430.94 & 35.67 & 40.67 \\
\hline & $\begin{array}{l}\text { Peat moss + } \\
\text { perlite }\end{array}$ & 20.00 & 22.00 & 18.67 & 21.00 & 322.26 & 342.44 & 33.67 & 36.67 \\
\hline & Rice straw & 15.00 & 19.33 & 13.00 & 18.67 & 262.24 & 264.10 & 24.33 & 27.67 \\
\hline & Compost & 18.67 & 20.67 & 16.33 & 19.00 & 265.75 & 269.30 & 30.67 & 29.00 \\
\hline \multicolumn{2}{|c|}{ L.S.D. at $5 \%$} & 1.17 & 1.24 & 1.13 & 1.44 & 20.74 & 32.90 & 2.22 & 1.94 \\
\hline
\end{tabular}


This result may be due to that mixing perlite with peat moss or coir lead to increasing the air space, water-holding capacity and aeration by organic substances as shown in pervious results in Table (2). These results agree also, with Gao et al. (2010) who reported that inorganic substances could partially replace organic substances. On the other hand, the lowest vegetative characters were obtained with rice straw or compost substrates, which have the lowest capacity for keeping water and nutrient elements. This result may be due to that $\mathrm{N}$ would not be readily available for the plants in rice straw substrates which may affect lettuce vegetative growth as reported by Gruda (2009). Moreover, the low total porosity in rice straw or compost substrates may lead to low oxygen levels in substrate which may be inhibited root respiration and decreased the amount of energy plant obtain from respiration and lead to affect plant growth as reported by (Schaffer 2006).

Concerning the interactions between all fertilizers and growing substrates, data in Table (4) showed significant effects on the previous growth characters. The most favorable beneficial interaction treatments regarding the previous growth characters were obtained in plants which planted on coir or peat moss with mineral fertilizers in the first and second seasons under investigation. While, the lowest vegetative growth was happened with the plants planted on rice straw with organic fertilizer.

\section{Head lettuce quality and yield:}

Results in Table (5) showed the effect of growing medium and fertilization on head firmness, surround, fresh and dry weight and total yield of lettuce crop grown in soilless culture system.

Concerning the effect of organic (Compost tea) and inorganic fertilization on the previous characteristic, data in Table (5) showed significant differences between organic and inorganic fertilization on these characteristics during the two studied seasons. Data showed that inorganic fertilization significantly lead to increase the head firmness, surround, fresh and dry weight as well as total yield $/ \mathrm{m}^{2}$ during the two studied seasons compared with organic fertilizer. However, there is little difference effect between the effect of fertigation with organic and inorganic fertilizers on the quality and yield of head lettuce. Results showed that organic nutrient solution decrease the head firmness, head surround, head weight, head dry weight and total yield of lettuce by $9.1 \%, 8.5 \%$, $13.3 \%, 18.3 \%$ and $13.3 \%$ respectively during the first season and by $5.9 \%, 5.5 \%, 12.4 \%, 22.8 \%$ and $12.4 \%$ for previous characters respectively during the second season in comparison to inorganic nutrient solution. The decrease in the previous characteristics due to the fertigation with compost tea may be due to the low concentrations of nutrients and increased soluble salts in this fertilizer as shown in Table (2).

Concerning the effect of growing medium on head lettuce quality and yield, data in Table (5) showed that, the maximum head firmness, surround, fresh and dry weight and total yield of lettuce crop were observed in plants grow on peat moss and coir substrates with no significant in between them followed by substrates mixture i.e. Peat moss + Perlite and Coir + Perlite compared to the other organic and inorganic media during the two studied seasons. These results may be due to the physical characters of these substrates as shown in previous results which have benefit effects on improving the head lettuce quality and yield during the two studied seasons. This result agrees with Gruda (2009) who states that, the chosen is possible to improve the quality of fruit by suitable substrate. Similar results were obtained by Gao et al., (2010) who reported that peat moss and their mixes with perlite are the most widely used substrates in growing and produce several vegetable crops. On the other hand, the lowest head lettuce quality and yield were obtained with rice straw or compost substrates which have the lowest capacity for keeping water and nutrient elements. This result may be due to that $\mathrm{N}$ would not be readily available for the plants on rice straw substrates, which affect lettuce growth as reported by Gruda (2009). Moreover, the low total porosity in rice straw or compost substrates may lead to low oxygen levels in the substrate which may inhibit root respiration and decrease the obtained amount of energy in the plant from respiration and lead to affect plant growth and yield as reported by (Schaffer 2006).

Concerning the interactions between all fertilizers and growing substrates, data in Table (5) showed significant effects on the head firmness, surround, fresh and dry weight as well as total yield of lettuce. The most favorable beneficial interaction treatments regarding the previous head lettuce quality and yield were produced in plants which planted on coir or peat moss with mineral fertilizers in the first and second seasons under investigation. The results indicated also, that the lettuce plants grown on the coir or peat moss followed by substrates mixture i.e. Peat moss + Perlite and Coir + Perlite substrate with organic solution grew healthier but had little small head firmness, surround, weight, dry weight and yield in comparison to inorganic nutrient solution on the same substrates. On the other hand, the lowest head lettuce quality and yield was happened with the plants planted on rice straw with organic fertilizer. 
Table 5. Effect of different substrates with organic and inorganic fertilization that associated with closed system on head firmness, surround, weight and total yield $\mathrm{kg} / \mathrm{m}^{2}$ ) of lettuce

\begin{tabular}{|c|c|c|c|c|c|c|c|c|c|c|c|}
\hline \multirow{2}{*}{\multicolumn{2}{|c|}{$\begin{array}{l} \\
\text { Treatments }\end{array}$}} & \multicolumn{2}{|c|}{$\begin{array}{l}\text { Head firmness } \\
\quad\left(\mathrm{kg} / \mathrm{cm}^{2}\right)\end{array}$} & \multicolumn{2}{|c|}{$\begin{array}{l}\text { Head surround } \\
\qquad(\mathrm{cm})\end{array}$} & \multicolumn{2}{|c|}{$\begin{array}{l}\text { Head fresh weight } \\
\text { (g) }\end{array}$} & \multicolumn{2}{|c|}{$\begin{array}{l}\text { Head dry weight } \\
\text { (g) }\end{array}$} & \multicolumn{2}{|c|}{$\begin{array}{c}\text { Total yield } \\
\left(\mathrm{kg} / \mathrm{m}^{2}\right)\end{array}$} \\
\hline & & 2016 & 2017 & 2016 & 2017 & 2016 & 2017 & 2016 & 2017 & 2016 & 2017 \\
\hline \multicolumn{2}{|c|}{ Mineral fertilizer } & 2.42 & 2.54 & 36.92 & 39.54 & 372.95 & 466.65 & 23.27 & 27.81 & 6.71 & 8.40 \\
\hline \multicolumn{2}{|c|}{ Organic fertilizer } & 2.20 & 2.39 & 33.77 & 37.35 & 323.33 & 408.9 & 19.00 & 21.47 & 5.82 & 7.36 \\
\hline \multicolumn{2}{|c|}{ L.S.D. at $5 \%$} & 0.05 & 0.01 & 0.26 & 0.27 & 22.81 & 36.12 & 0.86 & 0.41 & 0.41 & 0.65 \\
\hline \multicolumn{2}{|l|}{ Coir } & 2.51 & 2.65 & 41.85 & 42.44 & 472.83 & 630.67 & 30.61 & 33.25 & 8.51 & 11.35 \\
\hline \multicolumn{2}{|l|}{ Perlite } & 2.29 & 2.49 & 34.37 & 37.38 & 311.83 & 350.95 & 18.33 & 20.33 & 5.61 & 6.32 \\
\hline \multicolumn{2}{|c|}{ Coir + perlite } & 2.40 & 2.63 & 37.90 & 40.24 & 356.00 & 402.50 & 20.73 & 26.38 & 6.41 & 7.25 \\
\hline \multicolumn{2}{|c|}{ Peat moss } & 2.52 & 2.66 & 41.97 & 42.98 & 484.67 & 632.33 & 29.23 & 33.46 & 8.72 & 11.38 \\
\hline \multicolumn{2}{|c|}{ Peat moss + perlite } & 2.41 & 2.63 & 38.36 & 41.13 & 337.50 & 413.00 & 21.25 & 26.14 & 6.08 & 7.43 \\
\hline \multicolumn{2}{|c|}{ Rice straw } & 1.97 & 2.07 & 25.43 & 31.29 & 220.17 & 303.33 & 13.26 & 15.45 & 3.96 & 5.46 \\
\hline \multicolumn{2}{|c|}{ Compost } & 2.07 & 2.14 & 27.56 & 33.67 & 254.00 & 331.67 & 16.12 & 17.50 & 4.57 & 5.97 \\
\hline \multicolumn{2}{|c|}{ L.S.D. at $5 \%$} & 0.04 & 0.01 & 0.48 & 1.13 & 8.18 & 21.81 & 0.86 & 0.55 & 0.15 & 0.39 \\
\hline \multirow{7}{*}{ Mineral } & Coir & 2.60 & 2.77 & 41.91 & 42.77 & 537.67 & 661.67 & 33.75 & 38.68 & 9.68 & 11.91 \\
\hline & Perlite & 2.37 & 2.50 & 35.32 & 39.05 & 309.67 & 354.9 & 20.03 & 22.15 & 5.57 & 6.39 \\
\hline & $\begin{array}{l}\text { Coir } \quad+ \\
\text { perlite }\end{array}$ & 2.57 & 2.74 & 38.37 & 40.37 & 331.67 & 414.00 & 20.57 & 29.06 & 5.97 & 7.45 \\
\hline & Peat moss & 2.62 & 2.78 & 43.83 & 44.04 & 585.67 & 716.33 & 36.04 & 40.36 & 10.54 & 12.89 \\
\hline & \multirow{2}{*}{$\begin{array}{l}\text { Peat moss } \\
\text { perlite } \\
\text { Rice } \\
\text { straw }\end{array}$} & 2.59 & 2.75 & 40.88 & 42.19 & 343.00 & 452.67 & 23.40 & 29.34 & 6.17 & 8.15 \\
\hline & & 2.05 & 2.10 & 28.50 & 32.61 & 246.67 & 322.33 & 14.08 & 16.80 & 4.44 & 5.81 \\
\hline & Compost & 2.13 & 2.16 & 29.70 & 35.78 & 256.33 & 344.33 & 18.15 & 18.30 & 4.61 & 6.20 \\
\hline \multirow{7}{*}{ Organic } & Coir & 2.43 & 2.64 & 41.80 & 42.12 & 408.00 & 599.67 & 27.47 & 27.82 & 7.34 & 10.79 \\
\hline & Perlite & 2.20 & 2.47 & 33.42 & 35.71 & 314.00 & 347.00 & 16.62 & 18.51 & 5.65 & 6.25 \\
\hline & $\begin{array}{l}\text { Coir } \\
\text { perlite }\end{array}$ & 2.23 & 2.51 & 37.43 & 40.10 & 380.33 & 391.00 & 20.89 & 23.70 & 6.85 & 7.04 \\
\hline & Peat moss & 2.42 & 2.53 & 40.12 & 41.92 & 383.67 & 548.33 & 22.41 & 26.55 & 6.91 & 9.87 \\
\hline & $\begin{array}{l}\text { Peat moss } \\
+ \text { perlite }\end{array}$ & 2.22 & 2.50 & 35.84 & 40.07 & 332.00 & 373.33 & 19.09 & 22.95 & 5.98 & 6.72 \\
\hline & $\begin{array}{l}\text { Rice } \\
\text { straw }\end{array}$ & 1.90 & 2.04 & 22.34 & 29.98 & 193.67 & 284.00 & 12.44 & 14.09 & 3.49 & 5.11 \\
\hline & Compost & 2.02 & 2.12 & 25.46 & 31.57 & 251.67 & 319.00 & 14.09 & 16.70 & 4.53 & 5.74 \\
\hline \multicolumn{2}{|c|}{ L.S.D. at $5 \%$} & 0.05 & 0.02 & 0.67 & 1.59 & 11.58 & 32.92 & 1.22 & 0.75 & 0.21 & 0.56 \\
\hline
\end{tabular}

NPK and chlorophyll content of lettuce plant

Results in Table (6) showed the effect of growing medium and fertilization on nutrient contents i.e., $\mathrm{N}$, $\mathrm{P}, \mathrm{K}$ and chlorophyll reading of lettuce leaves, grown in soilless culture system.

Concerning the effect of organic (Compost tea) and inorganic fertilization on the previous characteristic, data in Table (6) showed significant differences between organic and inorganic fertilization of these characteristics during the two studied seasons. Data showed that, N, P, K, and chlorophyll reading had increased with using mineral fertilizer compared with organic fertilizer. At the same time, plant analysis showed that nutrient concentrations of lettuce plants grown on different substrates and fertigated with compost tea were in acceptable range for all elements, however this range was smaller than the plants grown in the same substrates and fertigated with inorganic nutrient solution. This may be due to that the nutrients in mineral fertilizers are directly available for plant roots, whereas the availability of nutrients organic materials especially organic nitrogen are low. Similar conclusion was reported by Doaa, (2016) who reported that using mineral nutrition significantly affect NPK concentration in strawberry leaves compared with organic.

Concerning the effect of growing medium on nutrient content i.e., N, P, K and chlorophyll of lettuce leaves, data showed, that the maximum values 
of previous parameters were observed in plants that grow on peat moss and coir substrates with no significant in between them followed with substrates mixture i.e. Peat moss + Perlite and Coir + Perlite compared to the other organic and inorganic media during the two studied seasons. These results may be due to the physical and chemical characters of these substrates as shown in previous results which lead to benefit effect on the plant's ability to uptake water and nutrients (Fonteno, 1996).Similar result was reported by Alan et al. (1994) who found that, the best growth occurred in $100 \%$ peat, which may be due to that substrate has a large capacity to keep water and nutrient elements than other substrates. Also, Reed, (1996) reported that peat moss is an important factor for nutrient uptake. On the other hand, the lowest parameters of NPK and chlorophyll content of lettuce plant were obtained in rice straw or compost substrates. This result may be due to that $\mathrm{N}$ would not be readily available for the plants in rice straw substrates due to the rice straw decomposition affect the $\mathrm{N}$ content in lettuce as shown in Table (6). Therefore a shortage of $\mathrm{N}$ in lettuce plant will be appear as reported by Gruda, 2009 and Abd ElSattar et al., 2008.

According to the interaction effect of different fertilizers and growing substrates on $\mathrm{N}, \mathrm{P}, \mathrm{K}$ and chlorophyll content in leaves. Data showed that the maximum $\mathrm{N}, \mathrm{P}, \mathrm{K}$ and chlorophyll in leaves was observed in coir or peat moss with fertigation by mineral fertilizers in the two studied seasons. On the other hand, the lowest NPK and chlorophyll contents of lettuce plant were happened with the plants planted on rice straw or compost with organic fertilizer only.

Table 6. Effect of different substrates with organic and inorganic fertilization that associated with closed system on NPK and chlorophyll content of lettuce plant

\begin{tabular}{|c|c|c|c|c|c|c|c|c|c|}
\hline \multirow{2}{*}{\multicolumn{2}{|c|}{ treatments }} & \multicolumn{2}{|c|}{$\mathrm{N} \%$} & \multicolumn{2}{|c|}{$\mathrm{P} \%$} & \multicolumn{2}{|c|}{$\mathrm{K} \%$} & \multicolumn{2}{|c|}{$\begin{array}{l}\text { Chlorophyll } \\
\text { (SPAD) }\end{array}$} \\
\hline & & 2016 & 2017 & 2016 & 2017 & 2016 & 2017 & 2016 & 2017 \\
\hline \multicolumn{2}{|c|}{ Mineral fertilizer } & 4.20 & 4.37 & 0.50 & 0.58 & 4.09 & 4.53 & 42.28 & 45.09 \\
\hline \multicolumn{2}{|c|}{ Organic fertilizer } & 3.56 & 3.80 & 0.42 & 0.48 & 3.64 & 4.16 & 37.73 & 38.60 \\
\hline \multicolumn{2}{|c|}{ L.S.D. at $5 \%$} & 0.04 & 0.1 & 0.01 & 0.01 & 0.07 & 0.03 & 2.96 & 3.43 \\
\hline \multicolumn{2}{|c|}{ Coir } & 4.51 & 4.80 & 0.58 & 0.65 & 4.73 & 5.14 & 44.19 & 47.09 \\
\hline \multicolumn{2}{|c|}{ Perlite } & 3.82 & 4.07 & 0.43 & 0.52 & 3.62 & 4.04 & 37.08 & 39.67 \\
\hline \multicolumn{2}{|c|}{ Coir + perlite } & 4.31 & 4.43 & 0.51 & 0.59 & 3.95 & 4.77 & 42.22 & 43.50 \\
\hline \multicolumn{2}{|c|}{ Peat moss } & 4.65 & 4.95 & 0.60 & 0.65 & 4.40 & 5.11 & 44.92 & 47.91 \\
\hline \multicolumn{2}{|c|}{ Peat moss + perlite } & 4.21 & 4.35 & 0.46 & 0.59 & 4.12 & 4.51 & 42.08 & 43.64 \\
\hline \multicolumn{2}{|c|}{ Rice straw } & 2.75 & 2.76 & 0.30 & 0.33 & 2.98 & 3.32 & 34.37 & 34.98 \\
\hline \multicolumn{2}{|c|}{ Compost } & 2.93 & 3.28 & 0.37 & 0.40 & 3.24 & 3.50 & 35.17 & 36.15 \\
\hline \multicolumn{2}{|c|}{ L.S.D. at $5 \%$} & 0.06 & 0.1 & 0.01 & 0.01 & 0.06 & 0.02 & 1.47 & 2.1 \\
\hline \multirow{7}{*}{ Mineral } & Coir & 4.80 & 4.94 & 0.59 & 0.68 & 4.80 & 5.33 & 44.90 & 49.47 \\
\hline & Perlite & 4.25 & 4.47 & 0.50 & 0.62 & 3.79 & 4.42 & 39.60 & 43.63 \\
\hline & Coir + perlite & 4.63 & 4.72 & 0.52 & 0.63 & 4.18 & 4.75 & 43.50 & 44.53 \\
\hline & Peat moss & 5.20 & 5.34 & 0.69 & 0.71 & 4.87 & 5.38 & 47.90 & 52.77 \\
\hline & Peat moss + perlite & 4.72 & 4.92 & 0.53 & 0.65 & 4.53 & 4.96 & 43.70 & 45.53 \\
\hline & Rice straw & 2.85 & 3.03 & 0.3 & 0.33 & 3.17 & 3.28 & 38.00 & 39.66 \\
\hline & Compost & 2.97 & 3.19 & 0.39 & 0.42 & 3.26 & 3.55 & 38.40 & 40.07 \\
\hline \multirow{7}{*}{ Organic } & Coir & 4.21 & 4.65 & 0.57 & 0.61 & 4.65 & 4.94 & 43.49 & 44.71 \\
\hline & Perlite & 3.39 & 3.67 & 0.36 & 0.41 & 3.45 & 3.67 & 34.57 & 35.71 \\
\hline & Coir + perlite & 4.00 & 4.13 & 0.49 & 0.54 & 3.72 & 4.78 & 40.94 & 42.47 \\
\hline & Peat moss & 4.10 & 4.55 & 0.52 & 0.59 & 3.92 & 4.84 & 41.93 & 43.04 \\
\hline & Peat moss + perlite & 3.70 & 3.76 & 0.40 & 0.53 & 3.71 & 4.05 & 40.47 & 41.74 \\
\hline & Rice straw & 2.65 & 2.49 & 0.29 & 0.32 & 2.78 & 3.36 & 30.73 & 30.31 \\
\hline & Compost & 2.89 & 3.37 & 0.34 & 0.39 & 3.22 & 3.45 & 31.97 & 32.23 \\
\hline \multicolumn{2}{|c|}{ L.S.D. at $5 \%$} & 0.08 & 0.11 & 0.02 & 0.01 & 0.08 & 0.03 & 2.45 & 2.97 \\
\hline
\end{tabular}

\section{Conclusion}

The study revealed that, desirable physical and chemical properties of a substrate are essential to optimal lettuce crop performance and this crop require different substrate physical properties from the substrate along with best management practices to ensure this performance. Results indicated that lettuce grow best when average percentage of total porosity in substrates is between 86.6 to $91.0 \%$.
Therefore, the peat moss, coir, peat moss + perlite and coir + perlite conceder a suitable substrates for lettuce with mineral fertigation in hydroponics culture. Moreover, the fertigation in the previous substrates by use compost tea solution lead to completed lettuce life cycles and appeared visually healthier plants but smaller heads than the plants grown in the same substrates and fertigated with inorganic nutrient solution. Therefore we can use this 
treatment with demand for "organic" production without chemicals utilized.

\section{References}

Abd El-Sattar, M.A.; H.A. El-Marzoky and A.I. Mohamed 2008. Occurrence of soil born diseases and rootknot nematodes in strawberry plants grown on compacted rice straw bales compacted with naturally infested soils. J. Plant Protec. Res.0 48 (2): 223-235.

Abu-Zahra, T.R. and A.B. Tahboub 2008. Effect of organic matter sources on chemical properties of the soil and yield of strawberry under organic farming conditions. World Appl Sci J. 5:383388.

Alan, R.; A. Zuladir and H. Padem 1994. The influence of growing media on growth, yield, and quality of tomato grown under greenhouse conditions Acta Hortic., 366, 429-436

Bergeron, M. 1994. Peat. Canadian Minerals Yearbook. Natural Resources Canada: Ottawa, 37.1-37.8.

Bohlin, C. and P. Holmberg 2004. Peat dominating growing medium in Swedish horticulture. Acta Hortic., 644, 177-181.

Böhme, M.; J. Schevchenko; I. Pinker and S. Herfort 2008. Cucumber grown in sheep wool slabs treated with biostimulator compared to other organic and mineral substrates. Acta Hortic., 779, 299-306

Brown, J. D. and M. Lilliand 1964. Rapid determination of potassium and socilium in plant material and soil extracts by phom photometry, proc. Amer. Soc. Hort. Sci., 48:341-346.

Bunt, A.C. 1984. Physical properties of mixtures of peats and minerals of different particle size and bulk density for potting substrates. ISHS Acta Hortic., 150: International Symposium on Substrates in Horticulture other than Soils in Situ

Carrijo, O.A.; M.C. Vidal; N.V.B. Reis; R.B. Souza and N. Makishima. 2004. Tomato crop production under different substrates and greenhouse models. Horticultura Brasileira., 22(1) 5-9.

Doaa, A. M. Gad. 2016. Effect of some nutrient solutions and different substrate mixtures on growth, yield and quality of strawberry plants under soilless culture conditions. Ph.D. thesis, College of Agriculture Cairo Univ.Egypt, pp. 127.

Donnan, R. 1998. Hydroponics around the world. Practical Hydroponics \& Greenhouses, 41: 18-25

Fahima, H. Ayob.; M.G.A. Gharib and M.H. Zaky 2013. Effect of different substrates mixtures on production the high-quality cucumber seedlings and its impact in growth and production of cucumber plants under greenhouse condition. Egypt. J. Appl. Sci., 28 (10): 681-708.
Filgueira, F. A. R. 2003. Novo manual de olericultura: agro tecnologia naprodução e comercialização de hortaliças. 2. ed. Viçosa: UFV, 402p.

Fonteno, W.C. 1996. Growing media types and physical/chemical properties. In: Reed, D.W. (Ed.), Water, Media and Nutrition for Greenhouse Crops. A Grower's Guide. Ball Publishing, Batavia, Illinois, USA. pp: 93-122.

Gao, H. B.;T. J. Zhang; G. Y. Lv; G. H. Zhang; X. L. $\mathrm{Wu}$; J. R. Li; and B. B. Gong 2010. Effects of different compound substrates on growth, yield and fruit quality of cucumber. Acta Hortic., 856, 173-180.

Gruda, N. 2009. Do soilless culture systems have an influence on product quality of vegetables $\mathrm{J}$. Applied Botany and Food Quality., 82, 141-147.

Grunert, O.; M. Perneel and S. Vandaele 2008. Peat based organic grow bags as a solution to the mineral wool water problem. Mires and Peat 3,15

Hernández-Apaolaza, L.; A. M. Gascó; J. M Gascó and F. Guerrero 2005. Reuse of waste materials as growing media for ornamental plants. Bioresource Techno., 96:125-131

Herrera F.; J. E. Castillo; A.F. Chica and L. LopezBellido. 2008. Use of municipal solid waste compost (MSWC) as a growing medium in the nursery production of tomato plants. Bioresource Techn., 99(2): 287- 296.

Jakson, M. L. 1973. Soil chemical analysis prenticeHall of India private limited, New Delhi.

Kang, J.Y.; H.-H. Lee and K.-H. Kim 2004. Physical and chemical properties of inorganic horticultural substrates used in Korea. Acta Hortic., 644(32): 237-241.

Litterick, A; L. Harrier; P. Wallance; C.A. Watson and M.Wood 2004. The role of uncomposted materials, composts, manures and compost extracts in reducing pest and disease incidence and severity in sustainable temperate agricultural and horticultural crop production- a review. Plant Sci. , 23:453-479

Meerow, A.W. 1994. Growth of two subtropical ornamentals using coir as a peat substitute. Hort. Sci., 29:1484-1486

Meerow, A. W. 2007. Coir dust, a viable alternative to peat moss. Viewed on Monday September 26, 2011. Available at: http://flrec.ifas.ufl.edu/Hort/Environmental/Medi a_Nutrition/COIR\%20potential.htm

Michael, R. and J. H. Lieth 2008. Soilless culture: Theory and Practice. 1st Edition. Elsevier.

Naidu, Y.; S. Meon; J. Kadir and Y. Siddiqui 2010. Microbial starter for the enhancement of biological activity of compost tea. Int J. Agr. Biol., 12:51-56

Nederhoff, E. and C. Stanghellini 2010. Water Use Efficiency of Tomatoes in Greenhouses and 
Hydroponics. Practical Hydroponics and Greenhouses, 115: 52-59.

Noguera, P.; M. Aba; R. Puchades; A. Maquieira and V. Noguera 2003. Influence of particle size on physical and chemical properties of coconut coir dust as a container medium. Commun. Soil Sci. Plant Anal., 34:593-605.

Olle, M.; M. Ngouajio and A. Siomos 2012. Vegetable quality and productivity as influenced by growing medium: a review. Zemdirbyste = Agric., 99(4):399-408.

Pardossi, A.; G. Carmassi; C. Diara; L. Incrocci; R. Maggini and D. Massa 2011. Fertigation and Substrate Management in Closed Soilless Culture. Dipartimento di Biologiadelle Piante Agrarie, University pf Pisa, Pisa, Italy.

Plummer, D.T. 1971. An introduction to practical biochemistry. Mc. Grow Hill Book Company, U $\mathrm{k}, 278 \mathrm{pp}$

Perlite Canada 2010. Inc. Perlite: horticultural applications. Viewed on Wednesday October 6, 2010.

Available

at: http://www.perlitecanada.com/en/english.html

Raviv, M. 2002. Horticultural uses of composted materials. Acta Hort., 469:225-234

Reed, D. W. 1996. Water, media, and nutrition for greenhouse crops. Ball Publishing Inc. Illinois, USA.
San Bautista, A; R. Rueda; B. Pascual; J. Maroto, and S. Lopez- Galarza 2005. Influence of different substrates and nutrient solutions on the yields and the incidence of a biotic disorders of broccoli. Acta Hortic., 697, 275-280.

Schaffer, B. 2006. Effects of soil oxygen deficiency on avocado (Persea Americana Mill.) trees. International seminar: Manejodel Riego y Suelo en el Cultivo del Palto La Cruz, Chile. September 27-28.

Scheuerell, S.J. and W.F. Mahaffee 2002. Compost tea principals and prospects for plant disease control. Compost Sci Util., 10:313-338.

Snedecor, C.W. and W.G. Cochran 1980."Statistical methods" 6th ed. Lowauniv. Press, Ames, Iowa, U.S.A.

Tzortzakis, N. G. and C. D. Economakis 2008. Impacts of the substrate medium on tomato yield and fruit quality in soilless cultivation. Hortic.l Sci., 35, 83-89.

Yoshida, S.; M. Kitano, and H. Eguchi 1997. Growth of lettuce plants (Lactuca sativa L.) under control of dissolved $\mathrm{O}_{2}$ concentration in hydroponics. Biotronics, 26: 39-45.

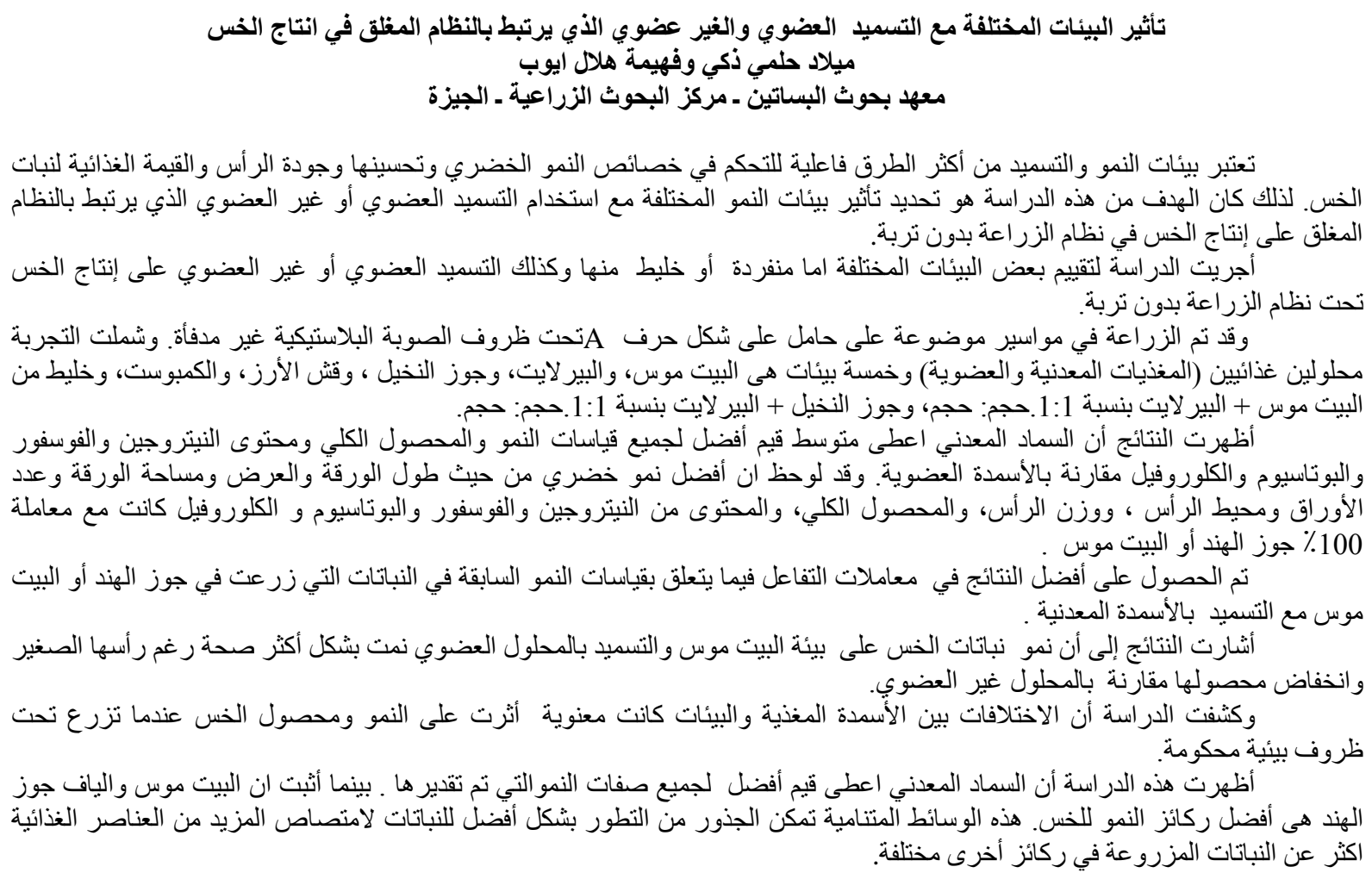

